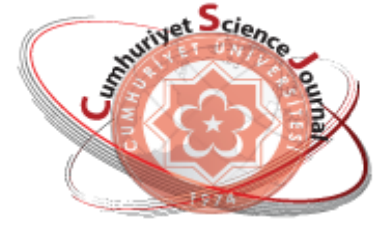

e-ISSN: $2587-246 X$

ISSN: $2587-2680$

\section{Cumanoriyot Science Journal}

est

Cumhuriyet Sci. J., Vol.40-1(2019) 150-157

\title{
Evaluation of Kinetic Effects of Baicalein in Different Breast Cancer Cell Lines
}

\author{
Mehmet Rıfkı TOPÇUL
}

University of Istanbul, Faculty of Science, Department of Biology, Istanbul, TURKEY

Received: 10.01.2019; Accepted: 25.02.2019

http://dx.doi.org/10.17776/csj.511141

\begin{abstract}
The aim of this study was to compare the antiproliferative effects of baicalein which is a flavonoide on MCF-7 and MDA-MB-231 cell line. The experiments were carried out with the evaluation of the parameters. Including cell viability, cell index, mitotic index, labelling index and apoptotic index. With the cell viability test, $\mathrm{IC}_{50}$ concentrations of baicalein for MCF-7 and MDA-MB-231 cells were determined as $10 \mu \mathrm{M}$ and 30 $\mu \mathrm{M}$, respectively and these concentrations were used in all experiments. The results showed that the $\mathrm{IC}_{50}$ concentrations decreased the values of cell viability, cell index, mitotic index and labelling index and increased the apoptotic index value for both cell types. These decreases and increases are statistically significant $(\mathrm{p}<0.01)$. In addition, curves of the graphs obtained from the xCelligence Real-Time Cell Analysis System showed that baicalein has cytoskeletal effects on MCF-7 cells and cytostatic effects on MDA-MB-231 cells. The results obtained from this study suggest that baicalein can be used in patients with luminal A and triple negative breast cancer in the clinic by supporting the future studies due to its antiproliferative effects on MCF-7 and MDAMB-231 cells.
\end{abstract}

Keywords: Baicalein, Luminal A breast cancer, Triple negative breast cancer.

\section{Baicalein'in Farklı Meme Kanseri Hücre hatlarındaki Kinetik Etkilerinin Değerlendirilmesi}

Özet. Bu çalışmada, bir flavonoid olan baicalein'in MCF-7 ve MDA-MB-231 hücre hatları üzerinde meydana getireceği antiproliferatif etkilerin karşılaştırılması amaçlanmıştır. Hücre canlılı̆̆ı, hücre indeksi, mitotik indeks, işaretlenme indeksi ve apoptotik indeks gibi hücre kinetiği parametrelerinin değerlendirilmesi ile deneyler gerçekleştirilmiştir.

Yapılan hücre canlılı̆̆ testi ile baicalein'in MCF-7 ve MDA-MB-231 hücreleri için IC 50 konsantrasyonları sırasıyla $10 \mu \mathrm{M}$ ve $30 \mu \mathrm{M}$ olarak belirlenmiş ve tüm deneylerde bu konsantrasyonlar kullanılmıştır. Elde edilen sonuçlar kullanılan $\mathrm{IC}_{50}$ konsantrasyonların her hücre tipi için de hücre canlılığı, hücre indeksi, mitotik indeks ve işaretlenme indeksi değerlerini azaltırken apoptotik indeks değerini yükselttiğini göstermiştir. Bu azalma ve artışlar istatistiksel olarak anlamlıdır $(\mathrm{p}<0.01)$. Ayrıca xCelligence Gerçek Zamanlı Hücre Analiz Sisteminden elde edilen grafiklere ait eğriler, baicalein'in MCF-7 hücrelerinde sitoskeletal etkiler meydana getirirken MDAMB-231 hücrelerinde sitostatik etki meydana getirdiğini göstermiştir. Bu çalışmadan elde edilen sonuçlar baicalein'in MCF-7 ve MDA-MB-231 hücreleri üzerine antiproliferatif etkilerinden dolayı ileride yapılacak çalışmalarla desteklenerek, klinikte luminal A ve üçlü negatif meme kanseri hastaları için de kullanılabileceğini düşündürmektedir.

Anahtar Kelimeler: Baicalein, Luminal A meme kanseri, Üçlü negatif meme kanseri. 


\section{INTRODUCTION}

Recent advances in cancer diagnosis and treatment have significantly improved the prognosis of breast cancer. However, metastasis is still the main cause of cancer death [1]. Breast cancer is the most common cancer type in women worldwide and is the second leading cause of cancer death. This disease is expected to constitute $29 \%$ of all new cancer diagnoses in the next 10 years [2].

Ductal breast cancer cells are the cells that protect many ideal features of the breast epithelium. These cells are known as ER +, PR + and HER2- and are the most common type of breast cancer. It represents a group with a chance of success in treatment because of the presence of targets such as ER and PR. Triple-negative breast cancer is negative for estrogen receptors, progesterone receptors, and excess HER2 protein. Such receptors are targets in the treatment of cancer and at the same time the absence of these targets causes triple negative breast cancer to be more aggressive than other types of breast cancer [3].

Polyphenolic compounds, flavonoids, are natural products found in many fruits, vegetables and all vascular plants [4]. Some flavonoid species include anticancer and chemopreventive activities [5-7]. Baicalein, a bioactive flavonoid extracted from the root of Scutellaria baicalensis or Scutellaria radix, has antitumor activity [8-10].

In this study, we aimed to evaluate cell proliferation by comparing cell kinetics induced by baicalein in two different types of breast cancer model MCF-7 and MDA-MB-231 cell lines.

\section{MATERIALS AND METHODS}

\subsection{Cell Culture}

MCF-7 cells used as luminal A breast cancer model and MDA-MB-231 cells used as triple negative breast cancer breast cancer were grown in Dulbecco's modified Eagle's medium (DMEM, high glucose) (Gibco: Thermo Fisher Scientific, Inc., Waltham, MA, USA) supplemented with 2 $\mathrm{mM}$ L-glutamine and $10 \%$ fetal bovine serum
(FBS; Gibco: Thermo Fisher Scientific, Inc.) plus antibiotics in a humidified atmosphere with $5 \%$ $\mathrm{CO}_{2}$ in air. The $\mathrm{pH}$ of the medium was adjusted to 7.4 with $\mathrm{NaHCO}_{3}$.

\subsection{Baicalein Concentrations}

The concentrations of baicalein (Tocris, 1761) were determined based on previous in vitro and clinical studies. $5 \mu \mathrm{M}, 10 \mu \mathrm{M}$ and $30 \mu \mathrm{M}$ concentrations were prepared for both cell lines. These concentrations were prepared by dilution of the $1 \mu \mathrm{M}$ stock solution with DMEM medium.

\subsection{Cell Viability Assay (CVA)}

Cell viability was examined using the MTT (Thiazolyl Blue Tetrazolium Bromide, Sigma, Missouri, USA) colorimetric assay. MCF-7 and MDA-MB-231 cells $\left(2 \times 10^{4}\right.$ cells per well $)$ on logarithmic growth phase were dispensed into 96well plate. After 24 hrs. incubation, baicalein concentrations were added to each well. At the end of the experimental period, the medium in each well was removed and $40 \mu \mathrm{l}$ fresh MTT solution (5 $\mathrm{mg} / \mathrm{ml}$ in PBS) were added into each well and cells were incubated at $37^{\circ} \mathrm{C}$ for $4 \mathrm{hrs}$. After incubation, $1 \mathrm{ml}$ of DMSO (solublizing reagent) was added to each well and shaked thoroughly for $1 \mathrm{hr}$ on a shaker. Then, the absorbance of the samples was measured against a background control as a blank using an Elisa reader ( $\mu$ Quant, Bio-Tek Instruments Inc Vermont, USA) at 450-690 nm.

\subsection{Cell Index (CI)}

Real-time cell proliferation monitoring MCF-7 and MDA-MB-231 cells were seeded at densities of 10000 and 5000 cells/well, respectively, into an Eplate 16 (ACEA Biosciences, San Diego, CA) containing $100 \mu \mathrm{L}$ medium per well and monitored on the xCELLigence Real-Time Cell Analyzer Dual Plate (RTCA DP) instrument (ACEA Biosciences). When the cells entered log phase, the different baicalein concentrations were added to final concentrations of $5 \mu \mathrm{M}, 10 \mu \mathrm{M}$ and $30 \mu \mathrm{M}$. The cells were treated with baicalein for 
$24 \mathrm{~h}$ and incubated at $37^{\circ} \mathrm{C}$ in a $5 \% \quad \mathrm{CO}_{2}$ atmosphere. To calculate the half maximal inhibitory concentration $\left(\mathrm{IC}_{50}\right)$ values and proliferation of the cells, RTCA software v. 1.2.1 was used.

\subsection{Mitotic Index (MI)}

After fixation with Carnoy Fixative, MCF-7 and MDA-MB-231 were hydrolyzed by Feulgen method and stained with Giemsa and MI was scored using the following formula: $\mathrm{MI}=(\mathrm{n} / \mathrm{C})$ $\mathrm{x} 100$.

\subsection{Labelling Index (LI)}

Thirty minutes before fixation time, $1 \mu \mathrm{Ci} / \mathrm{ml}{ }^{3} \mathrm{H}$ thymidine was applied on MCF-7 and MDA-MB231 cells and the cells were marked. Slides were exposed at $4{ }^{\circ} \mathrm{C}$ for 3 days and then the cells were developed with D-19b. Each slide was stained with Giemsa and 3000 cells were counted to determine the LI values.

\subsection{Apoptotic Index (AI)}

MCF-7 and MDA-MB-231 cells were collected and then fixed with methanol: Phosphate-buffered saline (PBS) (1:1) and methanol. The cells were fixed and mounted on slides, stained with 0.5 $\mathrm{mg} / \mathrm{ml} \mathrm{DAPI} \mathrm{for} 30 \mathrm{~min}$ and washed with PBS. Nuclear morphology of the cells was visualized using an Olympus fluorescence microscope (Olympus Corp., Tokyo, Japan). For evaluation of the AI, at least 100 cells were counted for the control and each of the experimental groups.

\subsection{Statistical Analysis}

All cell proliferation values (CVA, MI, LI, AI) were evaluated relative to the controls and to each other. For this reason, the values obtained from all experimental groups were analyzed using the oneway ANOVA test. The significance between the control and the experimental groups was determined by the Dunnett's test and the significance between the experimental groups was determined by the Student's t-test. $\mathrm{P}<0.01$ was considered to indicate a statistically significant result.

\section{RESULTS}

\subsection{Cell Viability}

The absorbance values of baicalein on MCF-7 cell line used as luminal A breast cancer and MDAMB-231 cell line used as triple negative breast cancer at a concentration of $5 \mu \mathrm{M}, 10 \mu \mathrm{M}$ and 30 $\mu \mathrm{M}$ for 24 hours were decreased from $468,19 \times 10^{-}$ ${ }^{3}$ to $378,26 \times 10^{-3} ; 230,927 \times 10^{-3}$ and $118,351 \times 10^{-}$ ${ }^{3}$ respectively $5 \mu \mathrm{M}, 10 \mu \mathrm{M}$ and $30 \mu \mathrm{M}$ for MCF7 cells (Figure 1) and decreased from 375,17 x 10${ }^{3}$ to $297,26 \times 10^{-3} ; 236,89 \times 10^{-3}$ and $188,144 \times 10^{-}$

${ }^{3}$ respectively $5 \mu \mathrm{M}, 10 \mu \mathrm{M}$ and $30 \mu \mathrm{M}$ for MDAMB-231 cells (Figure 2). A statistically significant decrease in absorbance values was observed as a result of baicalein application for both cell lines at 24 h. $(\mathrm{p}<0.01)$.

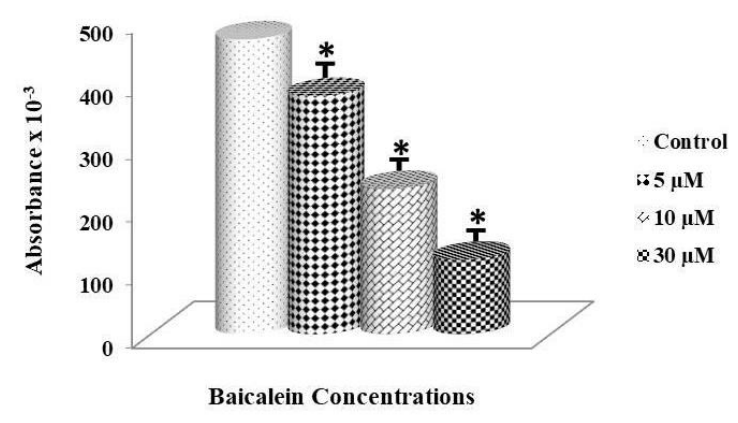

Figure 1. Absorbance values of MCF-7 cells treated with 5 $\mu \mathrm{M}, 10 \mu \mathrm{M}$ and $30 \mu \mathrm{M}$ Baicalein for $24 \mathrm{~h}(\mathrm{p}<0.01)$.

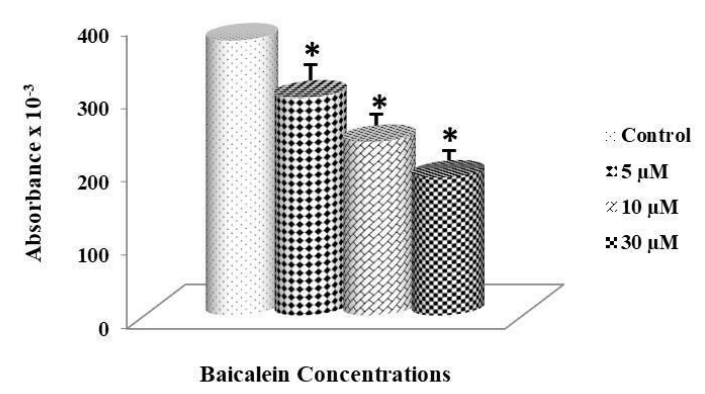

Figure 2. Absorbance values of MDA-MB-231 cells treated with $5 \mu \mathrm{M}, 10 \mu \mathrm{M}$ and $30 \mu \mathrm{M}$ Baicalein for $24 \mathrm{~h}(\mathrm{p}<0.01)$. 
The results indicated that $24 \mathrm{hrs}$ after the administration of baicalein concentrations to MCF7 cells, viability values were $80,79 \%$ for $5 \mu \mathrm{M}$, $49,32 \%$ for $10 \mu \mathrm{M}$ and $25,27 \%$ for $30 \mu \mathrm{M}$ compared to the control group which was considered as $100 \%$ (Figure 3). For MDA-MB231 cells, viability values were 79,23\%;63,14\% and $50,14 \%$ for respectively $5 \mu \mathrm{M}, 10 \mu \mathrm{M}$ and 30 $\mu \mathrm{M}$ compared to the control group which was considered as $100 \%$ (Figure 4). When the viability $\%$ values were examined, the $\mathrm{IC}_{50}$ value causing half of the cells in the culture was determined as 10 $\mu \mathrm{M}$ for MCF-7 cells and $30 \mu \mathrm{M}$ for MDA-MB-231 cells. All other experiments were performed using $\mathrm{IC}_{50}$ values of the cells.

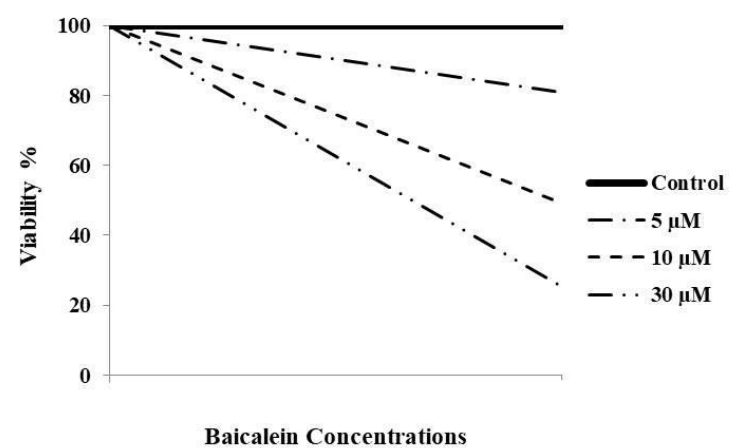

Figure 3. Percent viability values of MCF-7 cells treated with $5 \mu \mathrm{M}, 10 \mu \mathrm{M}$ and $30 \mu \mathrm{M}$ Baicalein for $24 \mathrm{~h}(\mathrm{p}<0.01)$.

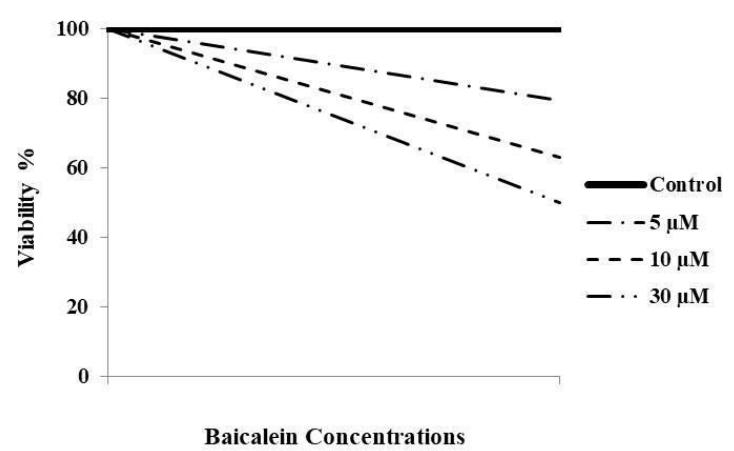

Figure 4. Percent viability values of MDA-MB-231 cells treated with $5 \mu \mathrm{M}, 10 \mu \mathrm{M}$ and $30 \mu \mathrm{M}$ Baicalein for $24 \mathrm{~h}$ $(\mathrm{p}<0.01)$.

When cell viability of MCF-7 cells for 72 hours were examined it was seen that absorbance values decreased from $468,19 \times 10^{-3}$ to $230,927 \times 10^{-3}$ for $24 \mathrm{~h}$; decreased from $522,367 \times 10^{-3}$ to $193,378 \times$ $10^{-3}$ for $48 \mathrm{~h}$ and decreased from $591,119 \times 10^{-3}$ to
$112,573 \times 10^{-3}$ for $72 \mathrm{~h}$ (Figure 5). For MDA-MB231 cell lines, these values decreased from 375,17 x $10^{-3}$ to $188,44 \times 10^{-3}$ for $24 \mathrm{~h}$; decreased from $401,16 \times 10^{-3}$ to $159,38 \times 10^{-3}$ for $48 \mathrm{~h}$ and decreased from $426,38 \times 10^{-3}$ to $106,33 \times 10^{-3}$ for $72 \mathrm{~h}$ (Figure 6).

It has been observed that a reduction in the rate of proliferation of both MCF-7 and MDA-MB-231 cells according to control in time dependent manner. This decrease is statistically significant at $\mathrm{p}<0.01$ level.

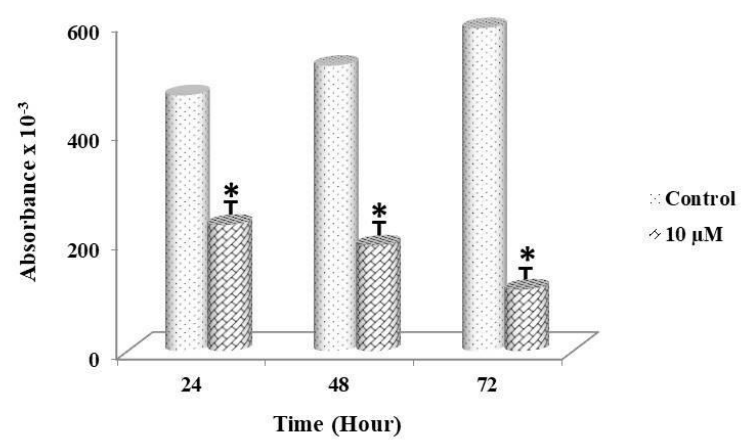

Figure 5. Absorbance values of MCF-7 cells treated with 10 $\mu \mathrm{M}$ Baicalein for $0-72 \mathrm{~h}(\mathrm{p}<0.01)$.

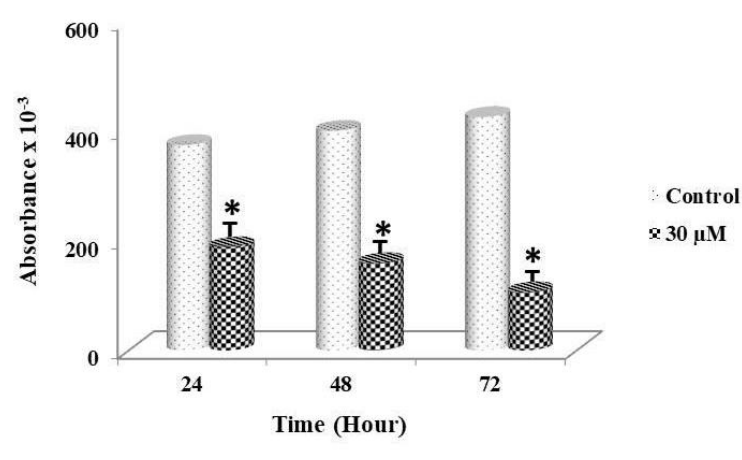

Figure 6. Absorbance values of MDA-MB-231 cells treated with $30 \mu \mathrm{M}$ Baicalein for $0-72 \mathrm{~h}(\mathrm{p}<0.01)$.

\subsection{Cell Index}

Cell index values obtained from xCELLigence RTCA system demonstrated that baicalein had significant anti-proliferative effects on both MCFand 7 MDA-MB-231 cell lines. Curves belong to graphics have suggested that $10 \mu \mathrm{M}$ baicalein has cytoskeletal effect on MCF-7 cells (Figure 7) while $30 \mu \mathrm{M}$ baicalein has cytostatic effect on MDAMB-231 cells (Figure 8). 


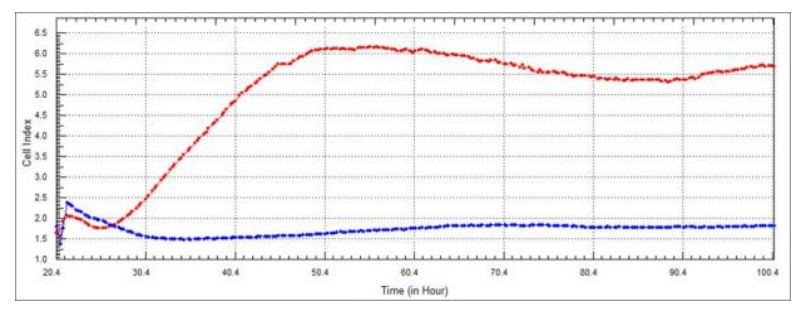

Figure 7. Cell index values of MCF-7 cells treated with $10 \mu \mathrm{M}$ Baicalein (Red line: Control, Blue line: $10 \mu \mathrm{M}$ ).

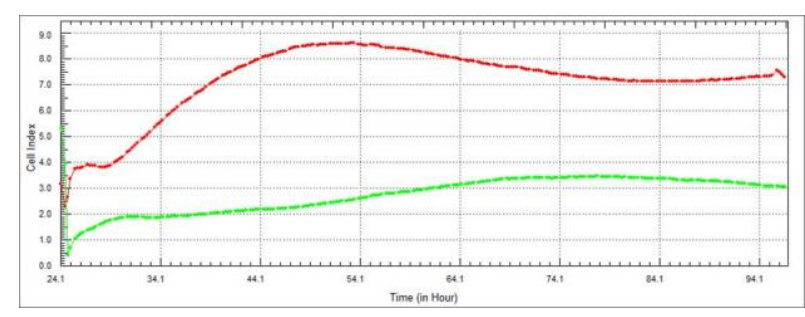

Figure 8. Cell index values of MDA-MB-231 cells treated with $30 \mu \mathrm{M}$ Baicalein (Red Line: Control, Yellow line: 30 $\mu \mathrm{M})$.

\subsection{Mitotic Index}

As a result of $10 \mu \mathrm{M}$ baicalein application to MCF7 cell line, mitotic index values decreased 5,12 to 2,51 at $24 \mathrm{~h}$; from 6,15 to 2,08 at $48 \mathrm{~h}$ and from 6,18 to 1,19 at $72 \mathrm{~h}$ (Figure 9). As a result of $30 \mu \mathrm{M}$ baicalein application to MDA-MB-231 cell line, mitotic index values decreased 4,21 to 2,26 at $24 \mathrm{~h}$; from 4,96 to 1,89 at $48 \mathrm{~h}$ and from 5,18 to 1,27 at $72 \mathrm{~h}$ (Figure 10). The mitotic index values obtained as a result of the baicalein application in the $\mathrm{IC}_{50}$ concentrations to MCF-7 and MDA-MB-231 cells for 72 hours showed a statistically significant decrease $(\mathrm{p}<0.01)$ in time dependent manner.

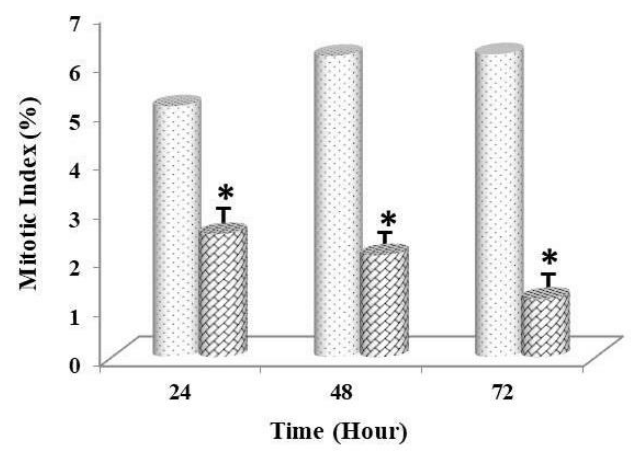

Figure 9. Mitotic index values of MCF-7 cells treated with 10 $\mu \mathrm{M}$ Baicalein for $0-72 \mathrm{~h}(\mathrm{p}<0.01)$.

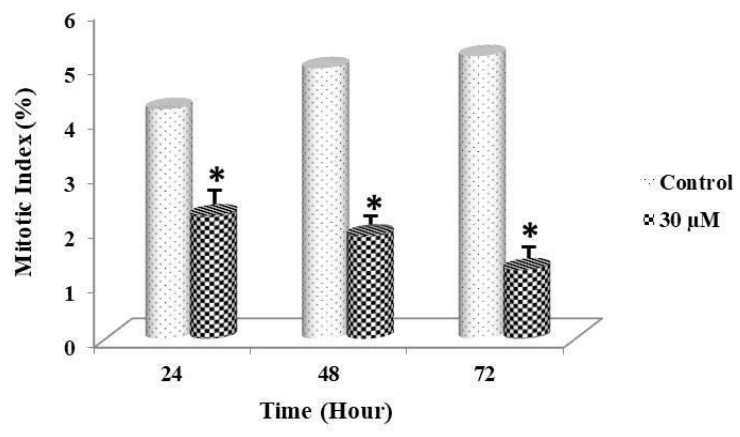

Figure 10. Mitotic index values of MDA-MB-231 cells treated with $30 \mu \mathrm{M}$ Baicalein for $0-72 \mathrm{~h}(\mathrm{p}<0.01)$.

\subsection{Labelling Index}

The labelling index values obtained as a result of the baicalein application in the $\mathrm{IC}_{50}$ concentrations to MCF-7 and MDA-MB-231 cells for 72 hours showed a statistically significant decrease $(\mathrm{p}<0.01)$ in time dependent manner. For MCF-7 cell line labelling index values decreased 4,59 to 2,97 at 24 $\mathrm{h}$; from 5,21 to 2,07 at $48 \mathrm{~h}$ and from 5,98 to 1,16 at $72 \mathrm{~h}$ (Figure 11). For MDA-MB-231 cell line apoptotic index values increased from 4,29 to 2,18 at $24 \mathrm{~h}$; from 4,58 to 1,57 at $48 \mathrm{~h}$ and from 5,11 to 1,08 at $72 \mathrm{~h}$ (Figure 12).

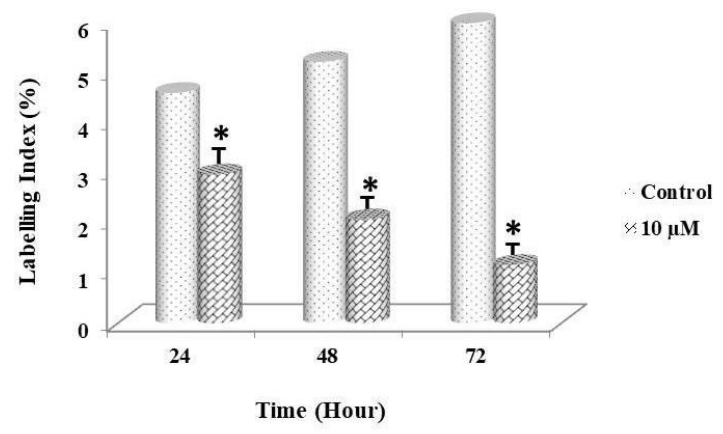

Figure 11. Labelling index values of MCF-7 cells treated with $10 \mu \mathrm{M}$ Baicalein for $0-72 \mathrm{~h}(\mathrm{p}<0.01)$.

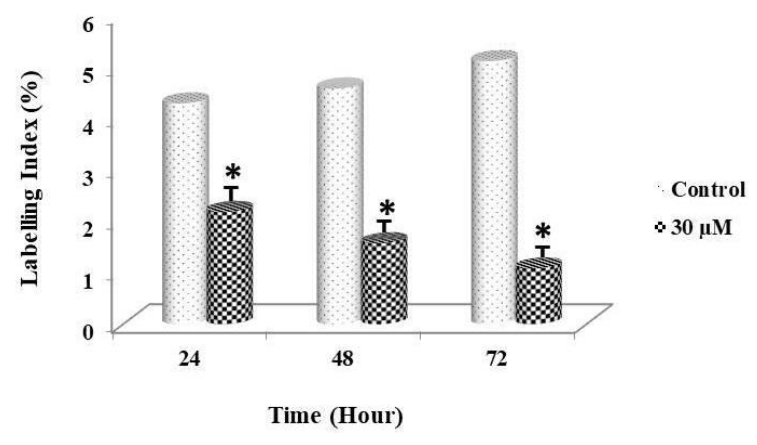

Figure 12. Labelling index values of MDA-MB-231 cells treated with $30 \mu \mathrm{M}$ Baicalein for $0-72 \mathrm{~h}(\mathrm{p}<0.01)$. 


\subsection{Apoptotic Index}

When the effects of baicalein at $\mathrm{IC}_{50}$ concentration on apoptotic index values of cells are evaluated, apoptotic index values of both MCF-7 and MDAMB-231 cells showed a statistically significant increase in time dependent manner $(p<0.01)$. For MCF-7 cell line apoptotic index values increased from 1,21 to 5,53 at $24 \mathrm{~h}$; from 1,18 to 9,18 at $48 \mathrm{~h}$ and from 2,59 to 14,29 at $72 \mathrm{~h}$ (Figure 13). For MDA-MB-231 cell line apoptotic index values increased from 1,92 to 4,78 at $24 \mathrm{~h}$; from 2,12 to 10,19 at $48 \mathrm{~h}$ and from 2,37 to 16,21 at $72 \mathrm{~h}$ (Figure 14).

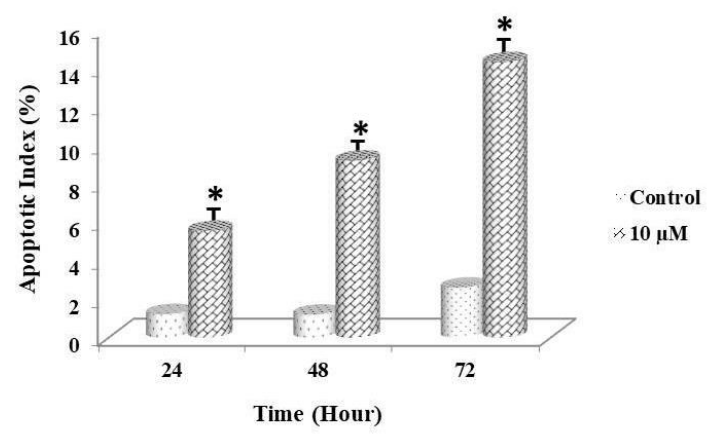

Figure 13. Apoptotic index values of MCF-7 cells treated with $10 \mu \mathrm{M}$ Baicalein for $0-72 \mathrm{~h}(\mathrm{p}<0.01)$.

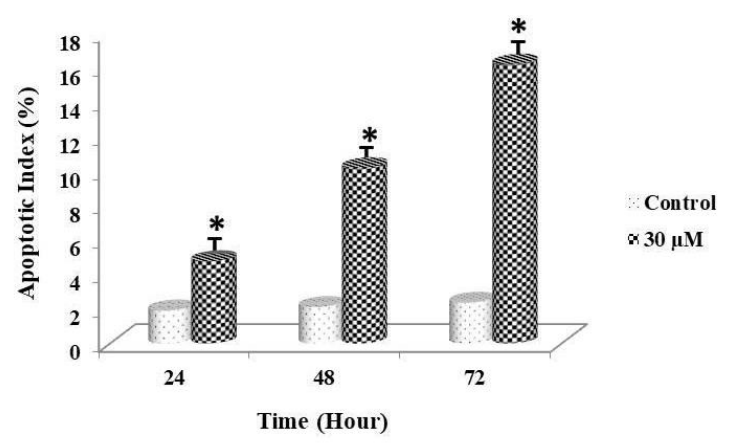

Figure 14. Apoptotic index values of MDA-MB-231 cells treated with $30 \mu \mathrm{M}$ Baicalein for $0-72 \mathrm{~h}(\mathrm{p}<0.01)$.

\section{DISCUSSION}

In this study evaluating the effects of baicalein on different types of breast cancer cell kinetics, results that support both previous research and new findings have been obtained. In a study evaluating the effect of baicalein on lung carcinoma cell line $\mathrm{CH} 27$ growth, different baicalein concentrations inhibited cell proliferation in dose and time dependent manner. Also cell cycle analysis with this cell line showed that S-phase arrest occurred as a result of 24-hour baicalein administration [11].

In a study of bladder cancer cell line BFTC 905, it was shown that baicalein inhibits cell proliferation in concentration dependent manner and high baicalein concentrations $(60-80 \mu \mathrm{mol} / \mathrm{L})$ completely block cell proliferation ability [12].

Studies performed with colorectal cancer cell line HCT116 showed that the cell proliferation was inhibited by the application of baicalein in a dose and time dependent manner [13].

In the gastric cancer cell line SGC7901, baicalein reduced cell proliferation in dose and time dependent manner, decreased percentage of $G_{1}$ phase cells while increased $S$ phase. Also the increase in the number of apoptotic nuclei containing condensed chromatin as a result of the application of baicalein also showed that baicalein induced apoptosis in gastric cancer cell line SGC7901 [14].

Baicalein has been shown to be an effective inhibitor of E2/IGF-1-induced cellular proliferation and colony formation in human breast carcinoma cells [15]. The ability of baicalein to bind to ER has also been confirmed by studies [16, 17]. In particular, baicalein antagonized estradioldependent estrogen-sensitive element response in a dose-dependent manner [18].

As a result of the application of different concentrations of baicalein to MCF-7 cells, the cell viability decreased gradually with increasing concentration. In addition, the TUNEL test also demonstrates that baicalein has an apoptosisenhancing effect on cells [19]. The above mentioned studies support our findings.

In a study that aimed to confirm the inhibitory effects of baicalein on MDA-MB-231 human breast cancer cells metastasis, MTT test was performed to evaluate the effect of baicalein on cell proliferation and it was observed that baicalein suppressed proliferation of MDA-MB-231 cells by 
dose and time dependent manner. Also it was also determined that baicalein suppressed the migration and invasion of cells by the wound healing assay [20].

As a result, baicalein inhibits cell proliferation at different optimum doses in MCF-7 and MDA-MB231 cells. The decrease in mitosis and synthesis phases suggests that the increase in apoptotic cells is due to different cell death mechanisms. The most important data supporting this idea is the findings obtained from the real-time cell analysis system. According to these findings, it is observed that MCF-7 cells go to death by cytoskeletal effect while MDA-MB-231 die with cytostatic effect. These data are supported by advanced studies and it is thought that Luminal A and triple negative breast cancer patients can benefit from baicalein.

\section{Acknowledgements}

The present study was supported by the Scientific Research Projects Coordination Unit of Istanbul University (Project no. 24288).

\section{REFERENCES}

[1]. Xie HY, Shao ZM and Li DQ., Tumor microenvironment: driving forces and potential therapeutic targets for breast cancer metastasis. Chin J. Cancer, 36 (2017) 36.

[2]. Siegel RL, Miller KD and Jemal A., Cancer statistics, 2016. C.A. Cancer J Clin., 66 (2016) 7-30.

[3]. Çetin İ, Topçul MR., Triple Negative Breast Cancer, APJCP. 15 (2014) 2427-243.

[4]. Di Carlo G, Mascolo N, Izzo AA, Capasso F., Flavonoids: old and new aspects of a class of natural therapeutic drugs. Life Sci., 65 (1999) 337-353.

[5]. Plaumann B, Fritsche M, Rimpler H, Brandner G, Hess RD., Flavonoids activate wild-type p53. Oncogene, 13 (1996) 16051614.

[6]. Naasani I, Oh-Hashi F, Oh-Hara T, et al., Blocking telomerase by dietary polyphenols is a major mechanism for limiting the growth of human cancer cells in vitro and in vivo. Cancer, 63 (2003) 824-830.
[7]. Kobayashi T, Nakata T, Kuzumaki T., Effect of flavonoids on cell cycle progression in prostate cancer cells. Cancer Lett., 176 (2002) 17-23.

[8]. Bonham M, Posakony J, Coleman I, Montgomery B, Simon J, Nelson PS., Characterization of chemical constituents in Scutellaria baicalensis with antiandrogenic and growth-inhibitory activities toward prostate carcinoma. Clin Cancer Res., 11 (2005) 3905-3914.

[9]. Miocinovic R, McCabe NP, Keck RW, Jankun J, Hampton JA, Selman SH., In vivo and in vitro effect of baicalein on human prostate cancer cells. Int J. Oncol., 26 (2005) 241-246.

[10].Ma Z, Otsuyama K, Liu S, et al., Baicalein, a component of Scutellaria radix from HuangLian-Jie-Du-Tang (HLJDT), leads to suppression of proliferation and induction of apoptosis in human myeloma cells. Blood, 105 (2005) 3312- 3318.

[11].Lee HZ, Leung HWC, Lai MY, Wu CH., Baicalein induced cell cycle arrest and apoptosis in human lung squamous carcinoma CH27 cells. Anticancer Res. 25 (2005) 959964.

[12].Chao JI, Su WC, Liu HF., Baicalein induces cancer cell death and proliferation retardation by the inhibition of CDC2 kinase and survivin associated with opposite role of p38 mitogenactivated protein kinase and AKT. Mol Cancer Ther., 6 (2007) 3039-3048.

[13].Chen Z, Hou R, Gao S, Song D, Feng Y., Baicalein inhibits proliferation activity of human colorectal cancer cells HCT116 through downregulation of ezrin. Cell Physiol Biochem., 49 (2018) 2035-2046.

[14].Mu J, Liu T, Jiang L, Wu X, Cao Y, Li M, Dong Q, Liu Y, Xu H., The Traditional Chinese medicine baicalein potently inhibits gastric cancer cells. Journal of Cancer, 7 (2016) 453-461.

[15].Lin CW, Yang LY, Shen SC and Chen YC., IGF-I plus E2 induces proliferation via activation of ROS-dependent ERKs and JNKs in human breast carcinoma cells. J Cell Physiol., 2012 (2007) 666-674. 
[16].Branham WS, Dial SL, Moland CL, Hass BS, Blair RM, Fang H, Shi L, Tong W, Perkins RG and Sheehan DM., Phytoestrogens and mycoestrogens bind to the rat uterine estrogen receptor. J Nutr., 132 (2002) 658-664.

[17].Shenouda NS, Zhou C, Browning JD, Ansell PJ, Sakla MS, Lubahn DB and Macdonald RS., Phytoestrogens in common herbs regulate prostate cancer cell growth in vitro. Nutr Cancer, 49 (2004) 200-208.

[18].Po LS, Chen ZY, Tsang DS, Leung LK., Baicalein and genistein display differential actions on estrogen receptor (ER) transactivation and apoptosis in MCF-7 cells. Cancer Lett., 187 (2002) 33-40.
[19].An H, Yu X, Xiang C, Zhang Y, Xia J, Wang Y., Original Article Baicalein and U0126 suppress human breast cancer cell line MCF7 through regulating MAPK signaling pathway. Int J Clin Exp Pathol., 9 (2016) 10266-10273.

[20].Ma X, Yan W, Dai Z, Gao X, Ma Y, Xu Q, Jiang J, Zhang S., Baicalein suppresses metastasis of breast cancer cells by inhibiting EMT via downregulation of SATB1 and Wnt/ $\beta$-catenin pathway. Drug Design, Development and Therapy, 10 (2016) 14191441. 